Article

\title{
Ceratinadins E and F, New Bromotyrosine Alkaloids from an Okinawan Marine Sponge Pseudoceratina sp.
}

\author{
Shin-ichiro Kurimoto ${ }^{1}$, Taito Ohno ${ }^{1}$, Rei Hokari ${ }^{2}$, Aki Ishiyama ${ }^{2}$, Masato Iwatsuki ${ }^{2}$, \\ Satoshi Ōmura ${ }^{2}$, Jun'ichi Kobayashi ${ }^{3}$ and Takaaki Kubota ${ }^{1, *}$ (i) \\ 1 Showa Pharmaceutical University, 3-3165 Higashi-Tamagawagakuen, Machida, Tokyo 194-8543, Japan; \\ kurimoto@ac.shoyaku.ac.jp (S.-i.K.); b13031@ug.shoyaku.ac.jp (T.O.) \\ 2 Kitasato Institute for Life Sciences, Kitasato University, 5-9-1 Shirokane, Minato-ku, Tokyo 108-8641, Japan; \\ hokari@lisci.kitasato-u.ac.jp (R.H.); ishiyama@lisci.kitasato-u.ac.jp (A.I.); iwatuki@lisci.kitasato-u.ac.jp (M.I.); \\ omuras@insti.kitasato-u.ac.jp (S.Ō.) \\ 3 Graduate School of Pharmaceutical Sciences, Hokkaido University, Sapporo 060-0812, Japan; \\ jkobay@pharm.hokudai.ac.jp \\ * Correspondence: kubota@ac.shoyaku.ac.jp; Tel.: +81-42-721-1574
}

Received: 20 October 2018; Accepted: 19 November 2018; Published: 23 November 2018

\begin{abstract}
Two new bromotyrosine alkaloids, ceratinadins E (1) and F (2), were isolated from an Okinawan marine sponge Pseudoceratina sp. as well as a known bromotyrosine alkaloid, psammaplysin F (3). The gross structures of $\mathbf{1}$ and $\mathbf{2}$ were elucidated on the basis of spectroscopic data. The absolute configurations of $\mathbf{1}$ and $\mathbf{2}$ were assigned by comparison of the NMR and ECD data with those of a known related bromotyrosine alkaloid, psammaplysin A (4). Ceratinadins E (1) and F (2) are new bromotyrosine alkaloids possessing an 8,10-dibromo-9-methoxy-1, 6-dioxa-2-azaspiro[4.6] undeca-2,7,9-trien-4-ol unit with two or three 11- $N$-methylmoloka'iamine units connected by carbonyl groups, respectively. Ceratinadin E (1) exhibited antimalarial activities against a drug-resistant and a drug-sensitive strains of Plasmodium falciparum (K1 and FCR3 strains, respectively).
\end{abstract}

Keywords: marine sponge; Pseudoceratina sp.; bromotyrosine alkaloid; ceratinadin; 1,6-dioxa-2azaspiro[4.6] undecane; 3,5-dibromotyramine; psammaplysin; moloka'iamine; antimalarial activity; Plasmodium falciparum

\section{Introduction}

According to the World Health Organization (WHO), 216 million clinical cases of malaria occurred and 445,000 people died of malaria in 2016 [1]. The representative antimalarial natural products, quinine and artemisinin, and their derivatives have been widely used for the treatment of malaria. However, the therapeutic efficacy of these existing antimalarial drugs is being lost due to the emergence and spread of drug-resistant strains of malaria. Therefore, the development of a new class of antimalarial drugs is urgently needed. Marine sponges have been recognized as a rich source of unique bioactive natural products. A variety of bromotyrosine alkaloids with a wide range of biological activities have been isolated from marine Verongid sponges [2] and references therein. The bromotyrosine alkaloids possessing the 1,6-dioxa-2-azaspiro[4.6]undecane skeleton, such as pammaplysins $F(3), G$, and $H$, and 19-hydroxypsammaplysin E, have been reported to exhibit antimalarial activity [3-6] Notably, psammaplysins F (3) and G showed antimalarial activities not only against the drug-sensitive strain but also against the drug-resistant strain of Plasmodium falciparum [4]. During our search for new bioactive natural products from marine organisms, a series of bromotyrosine alkaloids has been isolated from Okinawan marine Verongid sponges [7-11]. Recently, we have isolated two new bromotyrosine alkaloids possessing the 1,6-dioxa-2-azaspiro[4.6]undecane skeleton, 
ceratinadins E (1) and F (2), see Figure 1, from the extract of an Okinawan marine sponge Pseudoceratina sp. Here, we describe the isolation, structure elucidation, and antimalarial activity of 1 and 2.

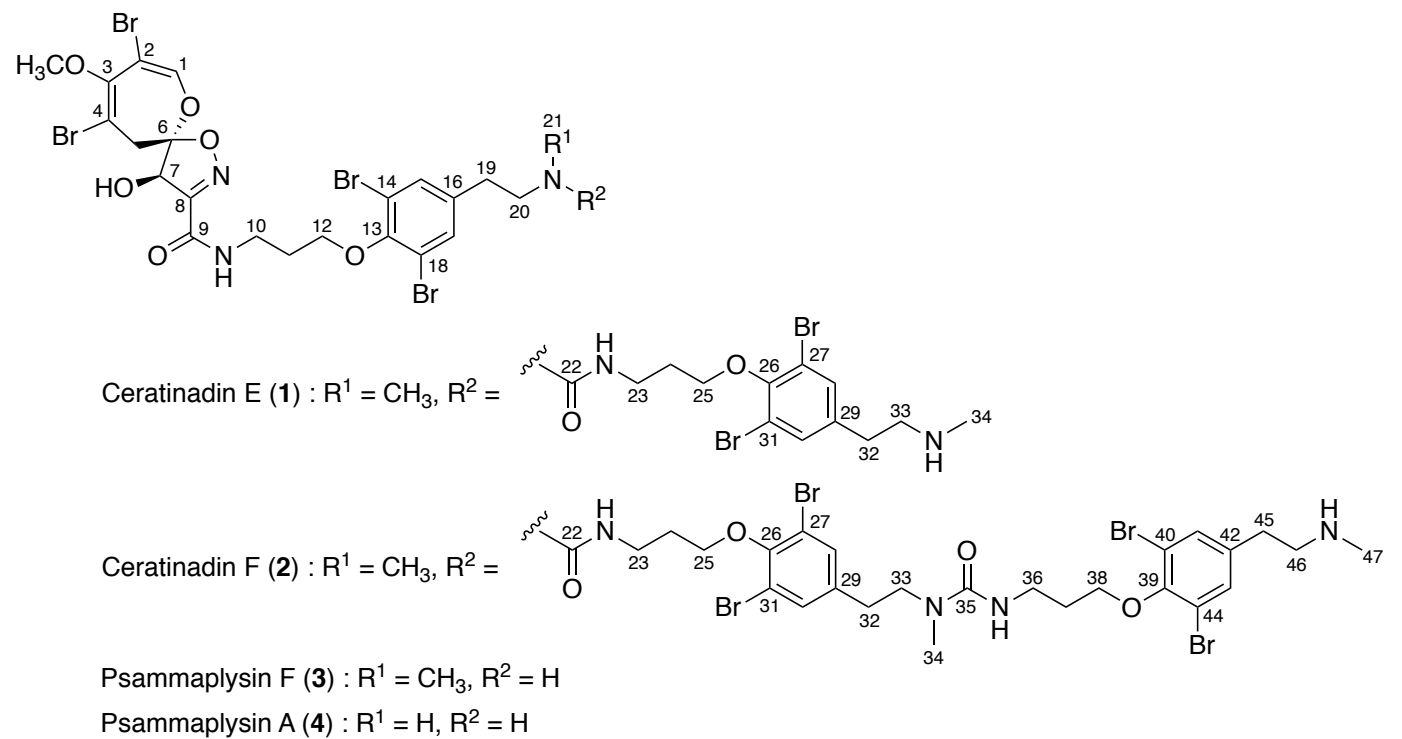

Figure 1. Structures of ceratinadins E (1) and F (2) and psammaplysins F (3) and A (4).

\section{Results}

The marine sponge Pseudoceratina sp. collected at Okinawa, Japan, was extracted with $\mathrm{MeOH}$, and the extract was partitioned between EtOAc and $\mathrm{H}_{2} \mathrm{O}$. The new bromotyrosine alkaloids, ceratinadins E (1, $4.6 \mathrm{mg}, 0.0073 \%$ wet weight) and F (2, $0.4 \mathrm{mg}, 0.00063 \%$ wet weight), were purified from the EtOAc-soluble material by silica gel column chromatography, short $\mathrm{C}_{18}$ column chromatography, $\mathrm{C}_{18}$ flash column chromatography, and $\mathrm{C}_{18}$ HPLC. A known related bromotyrosine alkaloid, psammaplysin F (3,10.8 mg, 0.017\% wet weight) [3,4], was obtained as well as 1 and 2 from the EtOAc-soluble material.

Ceratinadin E (1) was obtained as an optically active colorless amorphous solid. The ESIMS spectrum of 1 showed the pseudomolecular ion peaks at $m / z 1133,1135,1137,1139,1141,1143$, and $1145\left(1: 6: 15: 20: 15: 6: 1,[\mathrm{M}+\mathrm{H}]^{+}\right)$, indicating the presence of six bromine atoms, see Figures S1 and S2. The molecular formula of 1 was established as $\mathrm{C}_{35} \mathrm{H}_{41} \mathrm{Br}_{6} \mathrm{~N}_{5} \mathrm{O}_{8}$ by HRESIMS data, see Figure S3. The UV absorption at $263 \mathrm{~nm}$ was attributed to the substituted benzenoid chromophore. The IR absorption at $3338 \mathrm{~cm}^{-1}$ implied the existence of hydroxy and/or amino groups, while the IR absorption at $1671 \mathrm{~cm}^{-1}$ implied the existence of carbonyl groups. The inspection of the HSQC spectrum with the ${ }^{1} \mathrm{H}$ and ${ }^{13} \mathrm{C}$ NMR data disclosed that 1 consists of fifteen non-protonated carbons, five $\mathrm{sp}^{2}$ methines, one $\mathrm{sp}^{3}$ methine, eleven $\mathrm{sp}^{3}$ methylenes, and three methyls, see Table 1 and Figures S4, S5, and S7. The comparison of the ${ }^{1} \mathrm{H}$ and ${ }^{13} \mathrm{C}$ NMR data of 1 with those of known related bromotyrosine alkaloids, such as psammaplysins A (4) [12-14] and F (3), suggested that 1 possessed an 8,10-dibromo-9-methoxy-1,6-dioxa-2-azaspiro[4.6] undeca-2,7,9-trien-4-ol unit (C-1 C-8, 1-O, 2-Br, 3- $\mathrm{OCH}_{3}, 4-\mathrm{Br}, 6-\mathrm{O}, 7-\mathrm{OH}$, and 8-N) and two 11-N-methylmoloka'iamine [15] units (C-10 C-21, 9-N, 12-O, 14-Br, 18-Br, and 20-N; C-23 C-34, 22-N, 25-O, 27-Br, 31-Br, and 33-N). The correlations observed in the ${ }^{1} \mathrm{H}^{1} \mathrm{H}$ COSY and HMBC spectra of 1 supported the presumption, see Figure 1, Figures S6 and S8. The HMBC correlations between $N$-methylene protons $\mathrm{H}_{2}-20\left(\delta_{\mathrm{H}} 3.52\right)$ and a carbonyl carbon C-22 $\left(\delta_{\mathrm{C}} 161.2\right), N$-methyl protons $\mathrm{H}_{3}-21\left(\delta_{\mathrm{H}} 2.88\right)$ and $\mathrm{C}-22$, and $N$-methylene protons $\mathrm{H}_{2}-23\left(\delta_{\mathrm{H}} 3.45\right)$ and C-22 revealed that 20-N and 22-N were connected through a carbonyl group at C-22, see Figure 2. Though no correlation across the C-8-C-9 bond was observed in the HMBC spectrum of 1, the HMBC correlation between $N$-methylene protons $\mathrm{H}_{2}-10\left(\delta_{\mathrm{H}} 3.65\right)$ and a carbonyl carbon $\mathrm{C}-9\left(\delta_{\mathrm{C}} 161.5\right)$ and the molecular formula of 1 implied that C-8 and 9-N were connected through a carbonyl group 
at C-9, as shown in Figure 1. Thus, the gross structure of $\mathbf{1}$ was fully elucidated. The absolute configurations at C-6 and C-7 of $\mathbf{1}$ were assigned as $R$ and $R$, respectively, since the NMR data of the 8,10-dibromo-9-methoxy-1,6-dioxa-2-azaspiro[4.6] undeca-2,7,9-trien-4-ol moiety of 1 and the pattern of the ECD spectrum of $\mathbf{1}$, see Figure S9, were coincident with those of psammaplysin A (4), a known related bromotyrosine alkaloid whose absolute configuration was established.

Ceratinadin F (2) was obtained as an optically active colorless amorphous solid. The molecular formula of 2 was established as $\mathrm{C}_{48} \mathrm{H}_{57} \mathrm{Br}_{8} \mathrm{~N}_{7} \mathrm{O}_{10}$ by HRESIMS data, see Figures S10, S11, and S12. The spectroscopic data (UV, IR, and NMR spectra) of 2 were analogous to those of ceratinadin E (1) except for the integral values of ${ }^{1} \mathrm{H}$ NMR signals ascribed to 11-N-mehtylmoloka'iamine units were 1.5 times as large as that of $\mathbf{1}$, see Figures S13, S14, S15, S16, and S17. These data suggested that $\mathbf{2}$ was an analog of $\mathbf{1}$ possessing an additional 11- $\mathrm{N}$-methylmoloka'iamine unit at the terminal amino group of $\mathbf{1}$. The presumption was supported by the correlations observed in the ${ }^{1} \mathrm{H}-{ }^{1} \mathrm{H}$ COSY and HMBC spectra of 2 , see Figure 3. Since the NMR data of the 8,10-dibromo9-methoxy-1,6-dioxa-2-azaspiro[4.6]undeca-2,7,9-trien-4-ol moiety of 2 and the pattern of the ECD spectrum of 2, see Figure S18, were coincident with those of psammaplysin A (4), the absolute configurations at C-6 and C-7 of 2 were assigned as $R$ and $R$, respectively.

Table 1. ${ }^{1} \mathrm{H}$ and ${ }^{13} \mathrm{C}$ NMR data of ceratinadins $\mathrm{E}(\mathbf{1})$ and $\mathrm{F}(\mathbf{2})$ in $\mathrm{CD}_{3} \mathrm{OD}$.

\begin{tabular}{|c|c|c|c|c|c|c|c|c|c|}
\hline \multicolumn{5}{|c|}{ Ceratinadin E (1) } & \multicolumn{5}{|c|}{ Ceratinadin F (2) } \\
\hline Position & $\delta_{\mathrm{H}}{ }^{a}$ & Multi $(J$ in $\mathrm{Hz})$ & $\delta_{C}^{b}$ & Multi & Position & $\delta_{\mathrm{H}}{ }^{a}$ & Multi ( $J$ in $\mathrm{Hz})$ & $\delta_{C}^{b}$ & Multi \\
\hline 1 & 7.18 & $\mathrm{~s}$ & 147.6 & $\mathrm{~d}$ & 1 & 7.17 & $\mathrm{~s}$ & 147.6 & $\mathrm{~d}$ \\
\hline 2 & - & & 105.1 & $\mathrm{~s}$ & 2 & - & & 105.1 & $\mathrm{~s}$ \\
\hline 3 & - & & 150.7 & $\mathrm{~s}$ & 3 & - & & 150.7 & $\mathrm{~s}$ \\
\hline $3-\mathrm{OCH}_{3}$ & $3.69^{d}$ & $\mathrm{~s}$ & 60.1 & $\mathrm{q}$ & $3-\mathrm{OCH}_{3}$ & $3.69^{d}$ & $\mathrm{~s}$ & 60.1 & $\mathrm{q}$ \\
\hline 4 & - & & 105.3 & $\mathrm{~s}$ & 4 & - & & 105.3 & s \\
\hline $5 a$ & 3.40 & $\mathrm{~m}^{e}$ & 39.1 & $\mathrm{t}$ & $5 a$ & 3.41 & $\mathrm{~d}(16.4)$ & 39.1 & $\mathrm{t}$ \\
\hline $5 b$ & 3.11 & $\mathrm{~d}(15.7)$ & & & $5 b$ & 3.10 & $\mathrm{~d}(16.4)$ & & \\
\hline 6 & - & & 121.7 & $\mathrm{~s}$ & 6 & - & & 121.6 & $\mathrm{~s}$ \\
\hline 7 & 5.03 & $\mathrm{~s}$ & 81.2 & $\mathrm{~d}$ & 7 & 5.02 & $\mathrm{~s}$ & 81.2 & $\mathrm{~d}$ \\
\hline 8 & - & & 159.5 & $\mathrm{~s}$ & 8 & - & & 159.5 & $\mathrm{~s}$ \\
\hline 9 & - & & 161.5 & $\mathrm{~s}$ & 9 & - & & 161.5 & $\mathrm{~s}$ \\
\hline 10 & $3.65^{c}$ & $\operatorname{td}(6.6,1.2)$ & 38.8 & $\mathrm{t}$ & 10 & $3.65^{c}$ & $\operatorname{td}(6.6,2.7)$ & 38.8 & $\mathrm{t}$ \\
\hline 11 & $2.15^{c}$ & $\mathrm{dt}(6.6,6.6)$ & 31.3 & $t$ & 11 & $2.15^{c}$ & $\mathrm{dt}(6.6,6.6)$ & 31.3 & $t$ \\
\hline 12 & $4.08^{c}$ & $\mathrm{~m}^{e}$ & 72.9 & $\mathrm{t}$ & 12 & $4.08^{c}$ & $\mathrm{~m}^{e}$ & 72.9 & $\mathrm{t}$ \\
\hline 13 & - & & 153.5 & $\mathrm{~s}$ & 13 & - & & 153.5 & $\mathrm{~s}$ \\
\hline 14,18 & - & & 119.7 & $\mathrm{~s}$ & 14,18 & - & & 119.8 & $\mathrm{~s}$ \\
\hline 15,17 & 7.49 & $\mathrm{~s}$ & 135.2 & d & 15,17 & 7.49 & $\mathrm{~s}$ & 135.2 & d \\
\hline 16 & - & & 140.8 & $\mathrm{~s}$ & 16 & - & & 140.8 & $\mathrm{~s}$ \\
\hline 19 & $2.81^{c}$ & $\mathrm{t}(7.1)$ & 34.6 & $\mathrm{t}$ & 19 & $2.81^{c}$ & $\mathrm{~m}^{e}$ & 34.8 & $t$ \\
\hline 20 & $3.52^{c}$ & $\mathrm{t}(7.1)$ & 51.7 & $\mathrm{t}$ & 20 & $3.51^{c}$ & $\mathrm{~m}^{e}$ & 51.7 & $t$ \\
\hline 21 & $2.88^{d}$ & $\mathrm{~s}$ & 35.8 & $q$ & 21 & $2.88^{d}$ & $\mathrm{~s}$ & 35.8 & $q$ \\
\hline 22 & - & & 161.2 & $\mathrm{~s}$ & 22 & - & & 161.2 & $\mathrm{~s}$ \\
\hline 23 & $3.45^{c}$ & $\mathrm{~m}^{e}$ & 40.1 & $\mathrm{t}$ & 23 & $3.45^{c}$ & $\mathrm{~m}^{e}$ & 40.2 & $\mathrm{t}$ \\
\hline 24 & $2.06^{c}$ & $\mathrm{dt}(6.4,6.4)$ & 32.4 & $\mathrm{t}$ & 24 & $2.05^{c}$ & $\mathrm{~m}^{e}$ & 32.5 & $\mathrm{t}$ \\
\hline 25 & $4.09^{c}$ & $\mathrm{~m}^{e}$ & 73.7 & $\mathrm{t}$ & 25 & $4.08^{c}$ & $\mathrm{~m}^{e}$ & 73.7 & $t$ \\
\hline 26 & - & & 154.4 & $\mathrm{~s}$ & 26 & - & & 153.6 & $\mathrm{~s}$ \\
\hline 27,31 & - & & 120.3 & $\mathrm{~s}$ & 27,31 & - & & 119.8 & $\mathrm{~s}$ \\
\hline 28,30 & 7.59 & $\mathrm{~s}$ & 135.2 & d & 28,30 & 7.49 & $\mathrm{~s}$ & 135.2 & d \\
\hline 29 & - & & 138.0 & $\mathrm{~s}$ & 29 & - & & 140.7 & $\mathrm{~s}$ \\
\hline 32 & 2.98 & br t (7.6) & 33.0 & $\mathrm{t}$ & 32 & 2.81 & $\mathrm{~m}^{e}$ & 34.8 & $\mathrm{t}$ \\
\hline 33 & 3.27 & br t (7.6) & 51.9 & $\mathrm{t}$ & 33 & 3.52 & $\mathrm{~m}^{e}$ & 51.7 & $t$ \\
\hline \multirow[t]{12}{*}{34} & $2.70^{d}$ & $\mathrm{~s}$ & 34.7 & $q$ & 34 & $2.88^{d}$ & $\mathrm{~s}$ & 35.8 & $q$ \\
\hline & & & & & 35 & - & & 161.2 & s \\
\hline & & & & & 36 & $3.44^{c}$ & $\mathrm{~m}^{e}$ & 40.2 & $\mathrm{t}$ \\
\hline & & & & & 37 & $2.05^{c}$ & $\mathrm{~m}^{e}$ & 32.4 & $t$ \\
\hline & & & & & 38 & $4.05^{c}$ & $\mathrm{~m}^{e}$ & 73.6 & $\mathrm{t}$ \\
\hline & & & & & 39 & - & & 154.5 & $\mathrm{~s}$ \\
\hline & & & & & 40,44 & - & & 120.3 & $\mathrm{~s}$ \\
\hline & & & & & 41,43 & 7.56 & $\mathrm{~s}$ & 135.2 & d \\
\hline & & & & & 42 & - & & 138.0 & $\mathrm{~s}$ \\
\hline & & & & & 45 & 2.93 & br t $(7.8)$ & 33.0 & $t$ \\
\hline & & & & & 46 & 3.18 & $\mathrm{~m}^{e}$ & 51.9 & $t$ \\
\hline & & & & & 47 & $2.70^{d}$ & $\mathrm{~s}$ & 34.7 & $q$ \\
\hline
\end{tabular}

\footnotetext{
${ }^{a} 600 \mathrm{MHz} .{ }^{b} 150 \mathrm{MHz} .{ }^{c} 2 \mathrm{H} .{ }^{d} 3 \mathrm{H} .{ }^{e} J$-values were not determined because of overlapping with other signals.
} 


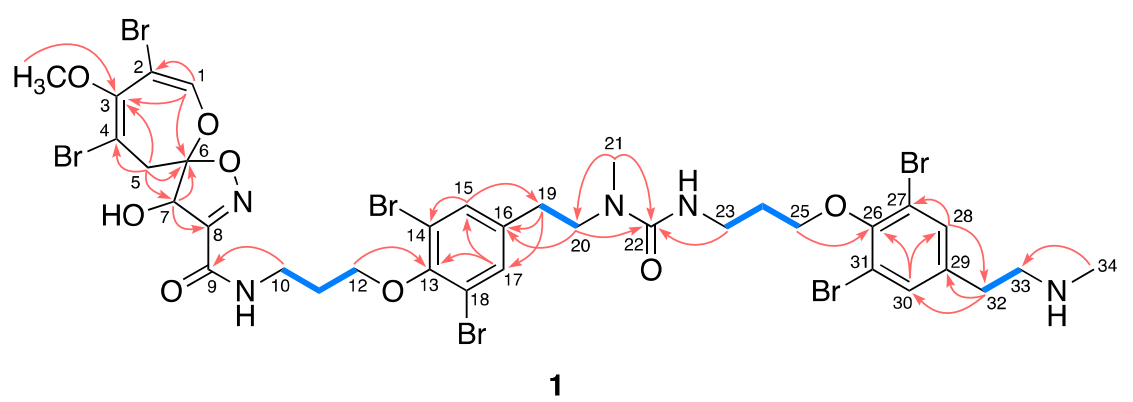

${ }^{1} \mathrm{H}-{ }^{1} \mathrm{H} \operatorname{COSY}$

$\mathrm{HMBC}$

Figure 2. Selected 2D NMR correlations for ceratinadin E (1).
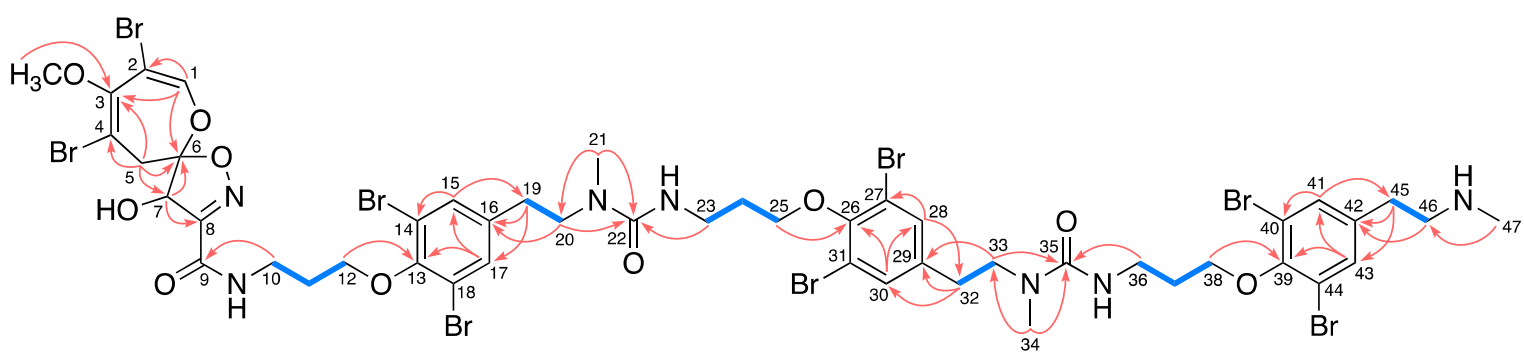

2

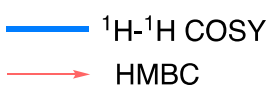

Figure 3. Selected 2D NMR correlations for ceratinadin F (2).

The antimalarial activities of psammaplysin F (3), ceratinadin E (1), and ceratinadin F (2) against a drug-resistant and a drug-sensitive strains of Plasmodium falciparum (K1 and FCR3 strains, respectively) were examined, see Table 2 [16]. Though the antimalarial activities of psammaplysin F (3) against a drug-resistant and a drug-sensitive strains of P. falciparum (Dd2 and 3D7 strains, respectively) were reported [3,4], 3 also exhibited antimalarial activities against $\mathrm{K} 1\left(\mathrm{IC}_{50} 3.77 \mu \mathrm{g} / \mathrm{mL}\right)$ and FCR3 $\left(\mathrm{IC}_{50}\right.$ $2.45 \mu \mathrm{g} / \mathrm{mL}$ ) strains in vitro. Ceratinadin E (1) exhibited slightly greater antimalarial activities against both $\mathrm{K} 1\left(\mathrm{IC}_{50} 1.03 \mu \mathrm{g} / \mathrm{mL}\right)$ and $\mathrm{FCR} 3\left(\mathrm{IC}_{50} 0.77 \mu \mathrm{g} / \mathrm{mL}\right)$ strains in vitro with better selectivity indexes than 3, while ceratinadin F (2) did not show significant antimalarial activity against the K1 strain $\left(\mathrm{IC}_{50}>12.5 \mu \mathrm{g} / \mathrm{mL}\right)$.

Table 2. Antimalarial activities of psammaplysin F (3), ceratinadin E (1), and ceratinadin F (2).

\begin{tabular}{cccccc}
\hline & \multicolumn{2}{c}{ Antimalarial Activity $^{\boldsymbol{a}}$} & Cytotoxicity $^{\boldsymbol{a}}$ & \multicolumn{2}{c}{ Selectivity Index } \\
\cline { 2 - 6 } & K1 $^{\boldsymbol{b}}$ & FCR3 $^{\boldsymbol{c}}$ & MRC-5 $^{\boldsymbol{d}}$ & MRC-5/K1 & MRC-5/FCR3 \\
\hline Psammaplysin F (3) & 3.77 & 2.45 & 12.65 & 3.4 & 5.2 \\
Ceratinadin E (1) & 1.03 & 0.77 & 15.99 & 15.5 & 20.8 \\
Ceratinadin F (2) & $>12.5$ & $-e$ & $>50$ & $>4$ & $-e$ \\
Chloroquine $^{f}$ & 0.34 & 0.035 & $>25.80$ & $>75.9$ & $>737.1$ \\
Artemisinin $^{f}$ & 0.010 & 0.0088 & $>14.12$ & $>1412$ & $>1604.5$ \\
\hline
\end{tabular}

${ }^{a} \mathrm{IC}_{50}(\mu \mathrm{g} / \mathrm{mL}) .{ }^{b}$ Drug-resistant $P$. falciparum strain. ${ }^{c}$ Drug-sensitive P. falciparum strain. ${ }^{d}$ Normal human embryonic lung fibroblast. ${ }^{e}$ not examined. ${ }^{f}$ Existing antimalarial drug.

\section{Discussion}

About five hundred bromotyrosine alkaloids have been isolated from marine Verongid sponges [2 and references therein]. Among them, thirty seven bromotyrosine alkaloids possessing the 1,6-dioxa-2-azaspiro[4.6] undecane skeleton have been reported from marine sponges belonging to the genus Aplysinella, Hyattella, Psedoceratina, and Suberea. The biosynthetic pathway of 3,5-dibromoL-tyrosine from L-phenylalanine and L-tyrosine by bromoperoxidase was proposed by Rinehert et al. [17]. 
Subsequently, the biosynthetic pathway of the 1,6-dioxa-2-azaspiro[4.6]undecane skeleton from 3,5-dibromo-L-tyrosine was proposed by Scheuer and Clardy et al. [13]. The antimalarial activity of eleven bromotyrosine alkaloids possessing the 1,6-dioxa-2-azaspiro[4.6] undecane skeleton have been examined so far and psammaplysins $\mathrm{F}$ (3) and $\mathrm{H}$ and 19-hydroxypsammaplysin $\mathrm{E}$ were known to exhibit the significant activity [4-6]. Though psammaplysin F (3) displayed the most potent activity against a drug-resistant strain of $P$. falciparum (Dd2 strain) among those compounds, ceratinadin E (1) showed the greater antimalarial activity against a drug-resistant strain of $P$. falciparum (K1 strain) in vitro with a better selectivity index than 3 . An additional $11-N$-methylmoloka'iamine unit might enhanced the activity, however ceratinadin $\mathrm{F}(2)$ did not show significant antimalarial activity. As Garson et al. reported that excessive lipophilicity decreases antimalarial activity [6], the lipophilicity of 2 might be too high. Though the antimalarial activity against drug-resistant strains of P. falciparum was unknown, psammaplysin $\mathrm{H}$, a derivative of 3 terminating in a trimethylaminium group instead of a methylamino group, exhibited the greater antimalarial activity against a drug-sensitive strain of P. falciparum than $\mathbf{3}$ without significant cytotoxicity. The antimalarial activity of the derivative of $\mathbf{1}$ terminating in a trimethylaminium group, which might be isolated from sponges or derived from $\mathbf{1}$, is quite fascinating.

\section{Materials and Methods}

\subsection{General Experimental Procedures}

The optical rotations were recorded on a JASCO P-2200 polarimeter. The UV spectra were recorded on a JASCO Ubest-55 spectrophotometer. The IR spectra were recorded on a JASCO FT/IR-420 spectrophotometer. The ECD spectra were recorded on a JASCO J-1500 spectropolarimeter. ${ }^{1} \mathrm{H}$ and ${ }^{13} \mathrm{C}$ NMR spectra were recorded on a Bruker Avance II $600 \mathrm{MHz}$ NMR spectrometer equipped with a cryoplatform using $3.0 \mathrm{~mm}$ micro cells (Shigemi Co., Ltd., Tokyo, Japan) for $\mathrm{CD}_{3} \mathrm{OD}$. The $3.35 \mathrm{ppm}$ resonance of residual $\mathrm{CD}_{2} \mathrm{HOD}$ in $\mathrm{CD}_{3} \mathrm{OD}$ was used as the internal references for ${ }^{1} \mathrm{H}$ NMR spectra. The $49.8 \mathrm{ppm}$ resonances of $\mathrm{CD}_{3} \mathrm{OD}$ were used as the internal reference for the ${ }^{13} \mathrm{C}$ NMR spectra. The MS spectra were recorded on a JEOL JMS-T100LP spectrometer. The flash column chromatography was performed with a Biotage Isolera flash purification system.

\subsection{Extraction and Isolation}

The sponge Pseudoceratina sp. (order Verongida; family Aplysinellidae) was collected at Okinawa, Japan. The sponge was kept frozen until used. The sponge $(0.4 \mathrm{~kg}$, wet weight $)$ was extracted with $\mathrm{MeOH}(500 \mathrm{~mL} \times 3)$ and the extract was concentrated in vacuo. The residue $(38.06 \mathrm{~g})$ was partitioned between EtOAc $(300 \mathrm{~mL} \times 3)$ and $\mathrm{H}_{2} \mathrm{O}(300 \mathrm{~mL})$ to afford the EtOAc-soluble material $(2.45 \mathrm{~g})$. A part of the EtOAc-soluble material (1.00 g) was fractionated by silica gel column chromatography [Silica gel 60N (spherical, neutral, 40-50 $\mu \mathrm{m}$ ), Kanto Chemical Co., Inc.; $38 \times 320 \mathrm{~mm}$; eluent $\mathrm{CHCl}_{3} / \mathrm{MeOH}$, 100:0 to 0:100] to give 12 fractions (Fr.1 12). A part (100.0 mg) of the fraction Fr.11 (257.6 mg) was passed through a short $\mathrm{C}_{18}$ column (Sep-Pak C18 Plus Short Cartridge, Waters; eluent MeOH, 100:0), and the eluted material $\left(90.4 \mathrm{mg}\right.$ ) was separated by $\mathrm{C}_{18}$ flash column chromatography (Isolera SNAP Ultra C18 $12 \mathrm{~g}$, Biotage; eluent $\mathrm{MeOH} / \mathrm{H}_{2} \mathrm{O} / \mathrm{TFA}, 10: 90: 0$ to 100:0:0.1) and $\mathrm{C}_{18}$ HPLC (COSMOSIL 5C 18 -AR-II, $10 \times 250 \mathrm{~mm}$, Nacalai Tesque Inc.; eluent $\mathrm{MeOH} / \mathrm{H}_{2} \mathrm{O} / \mathrm{TFA}, 60: 40: 0.1$; flow rate $2.5 \mathrm{~mL} / \mathrm{min}$; UV detection at $254 \mathrm{~nm}$ ) to yield psammaplysin $\mathrm{F}\left(3, t_{\mathrm{R}} 6.1 \mathrm{~min}, 10.8 \mathrm{mg}, 0.017 \%\right.$ wet weight), ceratinadin $\mathrm{E}\left(\mathbf{1}, t_{\mathrm{R}} 8.8 \mathrm{~min}, 4.6 \mathrm{mg}, 0.0073 \%\right.$ wet weight $)$, and ceratinadin $\mathrm{F}\left(\mathbf{2}, t_{\mathrm{R}} 15.6 \mathrm{~min}, 0.4 \mathrm{mg}, 0.00063 \%\right.$ wet weight).

\subsection{Ceratinadin $E(\mathbf{1})$}

Colorless amorphous solid; $[\alpha]_{\mathrm{D}}^{24}-45.1(c=0.48, \mathrm{MeOH})$; UV (MeOH) $\lambda_{\max } 206$ ( $\varepsilon$ 117744), 263 ( $\varepsilon$ 10233) nm; IR (film/KBr) $v_{\max } 3338,2935,2880,1671,1624,1541,1257,1200,1133 \mathrm{~cm}^{-1}$; ECD $(\mathrm{MeOH}) \lambda_{\max }(\Delta \varepsilon) 212(-17.44), 242(+7.73), 288(-1.14) \mathrm{nm} ;{ }^{1} \mathrm{H}$ NMR and ${ }^{13} \mathrm{C}$ NMR data, as shown in 
Table 1; ESIMS $m / z$ 1133, 1135, 1137, 1139, 1141, 1143, 1145 (1:6:15:20:15:6:1, [M + H] $\left.{ }^{+}\right)$; HRESIMS m/z $1139.80628[\mathrm{M}+\mathrm{H}]^{+}$(calcd for $\left.\mathrm{C}_{35} \mathrm{H}_{42}{ }^{79} \mathrm{Br}_{3}{ }^{81} \mathrm{Br}_{3} \mathrm{~N}_{5} \mathrm{O}_{8}, 1139.80722\right)$.

\subsection{Ceratinadin F (2)}

Colorless amorphous solid; $[\alpha]_{\mathrm{D}}^{24}-25.0(c=0.18, \mathrm{MeOH}) ; \mathrm{UV}(\mathrm{MeOH}) \lambda_{\max } 206$ ( $\left.\varepsilon 60692\right), 262$ ( $\varepsilon$ 4308) nm; IR (film/KBr) $v_{\max } 3413,2926,2849,1676,1581,1210,1183,1140 \mathrm{~cm}^{-1}$; ECD (MeOH) $\lambda_{\max }$ $(\Delta \varepsilon) 209(-11.32), 243(+4.34), 278(-0.18) \mathrm{nm} ;{ }^{1} \mathrm{H}$ NMR and ${ }^{13} \mathrm{C}$ NMR data, as shown in Table 1; ESIMS $m / z$ 1523, 1525, 1527, 1529, 1531, 1533, 1535, 1537, 1539 (1:8:28:56:70:56:28:8:1, [M + H] $\left.{ }^{+}\right) ;$HRESIMS m/z 1531.76647 [M + H] $]^{+}$(calcd for $\left.\mathrm{C}_{48} \mathrm{H}_{58}{ }^{79} \mathrm{Br}_{4}{ }^{81} \mathrm{Br}_{4} \mathrm{~N}_{7} \mathrm{O}_{10}, 1531.76303\right)$.

\section{Conclusions}

In conclusion, two new bromotyrosine alkaloids, ceratinadins E (1) and F (2), were isolated from an Okinawan marine sponge Pseudoceratina sp. as well as a known bromotyrosine alkaloid, psammaplysin F (3). Ceratinadins E (1) and F (2) are new bromotyrosine alkaloids possessing an 8,10-dibromo-9-methoxy-1,6-dioxa-2-azaspiro[4.6]undeca-2,7,9-trien-4-ol unit with two or three $11-N$-methylmoloka'iamine units connected by carbonyl groups, respectively. Ceratinadin E (1) and psammaplysin F (3) exhibited antimalarial activities against a drug-resistant and a drug-sensitive strains of Plasmodium falciparum (K1 and FCR3 strains, respectively) in vitro, while ceratinadin F (2) did not show significant antimalarial activity. Further isolation, structure elucidation, and structure-activity relationship studies of this type of alkaloids are required for the development of new antimalarial drugs.

Supplementary Materials: The following are available online at http:/ / www.mdpi.com/1660-3397/16/12/463/ s1, Figure S1: ESIMS spectrum (positive ion mode) of ceratinadin E (1), Figure S2: Expanded ESIMS spectrum (positive ion mode) of ceratinadin E (1), Figure S3: HRESIMS data (positive ion mode) of ceratinadin E (1), Figure S4: ${ }^{1} \mathrm{H}$ NMR spectrum of ceratinadin $\mathrm{E}(1)$ in $\mathrm{CD}_{3} \mathrm{OD}(600 \mathrm{MHz})$, Figure S5: ${ }^{13} \mathrm{C}$ NMR spectrum of ceratinadin $\mathrm{E}(\mathbf{1})$ in $\mathrm{CD}_{3} \mathrm{OD}(150 \mathrm{MHz})$, Figure S6: ${ }^{1} \mathrm{H}^{-}{ }^{1} \mathrm{H}$ COSY spectrum of ceratinadin $\mathrm{E}(\mathbf{1})$ in $\mathrm{CD}_{3} \mathrm{OD}$ $(600 \mathrm{MHz})$, Figure S7: HSQC spectrum of ceratinadin E (1) in $\mathrm{CD}_{3} \mathrm{OD}(600 \mathrm{MHz})$, Figure S8: HMBC spectrum of ceratinadin E (1) in $\mathrm{CD}_{3} \mathrm{OD}(600 \mathrm{MHz})$, Figure S9: ECD spectrum of ceratinadin E (1) in $\mathrm{CH}_{3} \mathrm{OH}$, Figure S10: ESIMS spectrum (positive ion mode) of ceratinadin F (2), Figure S11: Expanded ESIMS spectrum (positive ion mode) of ceratinadin F (2), Figure S12: HRESIMS data (positive ion mode) of ceratinadin F (2), Figure S13: ${ }^{1} \mathrm{H}$ NMR spectrum of ceratinadin $\mathrm{F}(2)$ in $\mathrm{CD}_{3} \mathrm{OD}(600 \mathrm{MHz})$, Figure $\mathrm{S} 14:{ }^{13} \mathrm{C}$ NMR spectrum of ceratinadin $\mathrm{F}(2)$ in $\mathrm{CD}_{3} \mathrm{OD}$ (150 MHz), Figure S15: ${ }^{1} \mathrm{H}-{ }^{1} \mathrm{H}$ COSY spectrum of ceratinadin $\mathrm{F}(2)$ in $\mathrm{CD}_{3} \mathrm{OD}(600 \mathrm{MHz})$, Figure S16: HSQC spectrum of ceratinadin $\mathrm{F}(2)$ in $\mathrm{CD}_{3} \mathrm{OD}(600 \mathrm{MHz})$, Figure S17: $\mathrm{HMBC}$ spectrum of ceratinadin $\mathrm{F}(2)$ in $\mathrm{CD}_{3} \mathrm{OD}$ (600 MHz), Figure S18: ECD spectrum of ceratinadin $\mathrm{F}(2)$ in $\mathrm{CH}_{3} \mathrm{OH}$.

Author Contributions: Conceptualization, M.I., S.Ō., J.K. and T.K.; Methodology, M.I., S.Ō., J.K. and T.K.; Validation, M.I. and T.K.; Investigation, S.K., T.O., R.H., A.I., M.I., J.K. and T.K.; Resources, J.K.; Data Curation, S.K., M.I. and T.K.; Writing-Original Draft Preparation, S.K. and T.O.; Writing-Review \& Editing, S.K. and T.K.; Visualization, S.K. and T.K.; Supervision, T.K.; Project Administration, T.K.; Funding Acquisition, S.K. and T.K.

Funding: This work was partly supported by a Grant-in-Aid for Young Scientists of Showa Pharmaceutical University, and JSPS KAKENHI Grant Numbers JP16K18903, JP17K08345.

Acknowledgments: We thank the late Z. Nagahama for his help with sponge collection, K. Chiba, The Instrument Analysis Equipment Research Center, Showa Pharmaceutical University, for measurements of MS.

Conflicts of Interest: The authors declare no conflict of interest.

\section{References}

1. World Health Organization. World Malaria Report 2017; WHO Press: Geneva, Switzerland, 2017.

2. Blunt, J.W.; Carroll, A.R.; Copp, B.R.; Davis, R.A.; Keyzers, R.A.; Prinsep, M.R. Marine natural products. Nat. Prod. Rep. 2018, 35, 8-53. [CrossRef] [PubMed]

3. Liu, S.; Fu, X.; Schmitz, F.J.; Kelly-Borges, M. Psammaplysin F, a new bromotyrosine derivative from a sponge, Aplysinella sp. J. Nat. Prod. 1997, 60, 614-615. [CrossRef] [PubMed] 
4. Yang, X.; Davis, R.A.; Buchanan, M.S.; Duffy, S.; Avery, V.M.; Camp, D.; Quinn, R.J. Antimalarial Bromotyrosine derivatives from the Australian marine sponge Hyattella sp. J. Nat. Prod. 2010, 73, 985-987. [CrossRef] [PubMed]

5. Xu, M.; Andrews, K.T.; Birell, G.W.; Tran, T.L.; Camp, D.; Davis, R.A.; Quinn, R.J. Psammaplysin H, a new antimalarial bromotyrosine alkaloid from a marine sponge of the genus Pseudoceratina. Bioorg. Med. Chem. Lett. 2011, 21, 846-848. [CrossRef] [PubMed]

6. Mudianta, I.W.; Skinner-Adams, T.; Andrews, K.T.; Davis, R.A.; Hadi, T.A.; Hayes, P.Y.; Garson, M.J. Psammaplysin derivatives from the Balinese marine sponge Aplysinella strangylata. J. Nat. Prod. 2012, 75, 2132-2143. [CrossRef] [PubMed]

7. Hirano, K.; Kubota, T.; Tsuda, M.; Watanabe, K.; Fromont, J.; Kobayashi, J. Ma'edamines A and B, cytotoxic bromotyrosine alkaloids with a unique $2(1 \mathrm{H})$ pyrazinone ring from sponge Suberea sp. Tetrahedron 2000, 56, 8107-8110. [CrossRef]

8. Mukai, H.; Kubota, T.; Aoyama, K.; Mikami, Y.; Fromont, J.; Kobayashi, J. Tyrokeradines A and B, new bromotyrosine alkaloids with an imidazolyl-quinolinone moiety from a Verongid sponge. Bioorg. Med. Chem. Lett. 2009, 19, 1337-1339. [CrossRef] [PubMed]

9. Kon, Y.; Kubota, T.; Shibazaki, A.; Gonoi, T.; Fromont, J.; Kobayashi, J. Ceratinadins A-C, new bromotyrosine alkaloids from an Okinawan marine sponge Pseudoceratina sp. Bioorg. Med. Chem. Lett. 2010, 20, 4569-4572. [CrossRef] [PubMed]

10. Kubota, T.; Watase, S.; Mukai, H.; Fromont, J.; Kobayashi, J. Tyrokeradines C-F, new bromotyrosine alkaloids from the Verongid sponges. Chem. Pharm. Bull. 2012, 60, 1599-1601. [CrossRef] [PubMed]

11. Kubota, T.; Watase, S.; Sakai, K.; Fromont, J.; Gonoi, T.; Kobayashi, J. Tyrokeradines G and H, new bromotyrosine alkaloids from an Okinawan Verongid sponge. Bioorg. Med. Chem. Lett. 2015, 25, 5221-5223. [CrossRef] [PubMed]

12. Rotem, M.; Carmely, S.; Kashman, Y. Two new antibiotics from the red sea sponge Psammaplysilla purpurea: Total ${ }^{13}$ C-NMR line assignment of psammaplysins A and B and aerothionin. Tetrahedron 1983, 39, 667-676. [CrossRef]

13. Roll, D.M.; Chang, C.W.J.; Scheuer, P.J.; Gray, G.A.; Shoolery, J.M.; Matsumoto, G.K.; Duyne, G.D.V.; Clardy, J. Structure of the psammaplysins. J. Am. Chem. Soc. 1985, 107, 2916-2920. [CrossRef]

14. Mándi, A.; Mudianta, I.W.; Kurtán, T.; Garson, M.J. Absolute configuration and conformational study of psammaplysins A and B from the Balinese marine sponge Aplysinella strongylata. J. Nat. Prod. 2015, 78, 2051-2056. [CrossRef] [PubMed]

15. Matsunaga, S.; Kobayashi, H.; van Soest, R.W.M.; Fusetani, N. Novel bromotyrosine derivatives that inhibit growth of the fish pathogenic bacterium Aeromonas hydrophila, from a marine sponge Hexadella sp. J. Org. Chem. 2005, 70, 1893-1896. [CrossRef] [PubMed]

16. Otoguro, K.; Kohana, A.; Manabe, C.; Ishiyama, A.; Ui, H.; Shiomi, K.; Yamada, H.; Ōmura, S. Potent antimalarial activities of polyether antibiotic, X-206. J. Antibiot. 2001, 54, 658-663. [CrossRef] [PubMed]

17. Tymiak, A.A.; Rinehert, K.L., Jr. Biosynthesis of dibromotyrosine-derived antimicrobial compounds by the marine sponge Aplysina fistularis (Verongia aurea). J. Am. Chem. Soc. 1981, 103, 6763-6765. [CrossRef]

(C) 2018 by the authors. Licensee MDPI, Basel, Switzerland. This article is an open access article distributed under the terms and conditions of the Creative Commons Attribution (CC BY) license (http:// creativecommons.org/licenses/by/4.0/). 